\title{
Інституту фізіології рослин і генетики Національної академії наук України - 70 років
}

\author{
В. В. Моргун, доктор біологічних наук, академік НАН \\ Інститут фізіології рослин і генетики Національної академії наук України \\ plant@ifrg.kiev.ua
}

Інститут фізіології рослин і генетики (ІФРГ) НАН України був заснований 15 травня 1946 р. на базі відділу фізіології живлення рослин і агрохімії Інституту ботаніки АН УРСР відповідно до постанови № 1692 від 20 жовтня 1945 р. Ради народних комісарів УРСР і Центрального комітету КП(б)У, яка надала дозвіл Президії АН УРСР організувати Інститут фізіології рослин і агрохіміï АН УРСР (перша назва установи).

Першим директором Інституту став відомий учений, агрохімік і фізіолог рослин, академік АН УРСР, заслужений діяч науки О. І. Душечкін. Складнощі з формуванням, пов'язані 3 повоєнним періодом, вдалося подолати шляхом залучення до роботи в Інституті провідних фізіологів і агрохіміків з інших наукових установ та вищих навчальних закладів Києва. Вони очолили основні напрями досліджень у створених ними відділах Інституту.

Одночасно до складу Інституту увійшло шість наукових відділів: агрохімії (завідувач - академік АН УРСР О. І. Душечкін), фізіології живлення (академік АН УРСР і ВАСГНІЛ П. А. Власюк), рослинництва та агромеліорації (д-р с.-г. наук, чл.-кор. АН УРСР М. О. Тюленєв), росту і розвитку рослин (чл.-кор. АН УРСР Т. Т. Демиденко), фізіології стійкості рослин (д-р с.-г. наук А. Г. Михаловський), біохімії рослин (д-р біол. наук А. С. Оканенко).

Розбудову Інституту почали зі створення у 1946 р. польової лабораторії (сьогодні - Дослідне сільськогосподарське виробництво) 3 дослідними полями навколо неї. Відділи Інституту територіально перебували у різних приміщеннях, а сучасний корпус Інституту був побудований лише у 1962 р.

У 1953 р. директором Інституту було став видатний фізіолог рослин, агрохімік і грунтознавець, заслужений діяч науки УРСР, академік АН УРСР і ВАСГНІЛ П. А. Власюк, який керував ним до 1973 р. За цей період змінювалися структура Інституту та його відомча підпорядкованість.

Так, у 1954 р. було створено відділ радіоізотопів і випромінювань, розформовано рослинництва та агромеліорації.
У 1956 р. Інститут увійшов до складу новоствореної Української академії сільськогосподарських наук, президентом якої став П. А. Власюк, і отримав назву Український науково-дослідний інститут фізіології рослин. У цей період відділ агрохімії був переданий Українському науково-дослідному інституту вемлеробства.

До складу Інституту входили такі підрозділи: застосування радіоактивних ізотопів (завідувач - канд. біол. наук А. В. Манорик); фізіології живлення рослин (д-р с.-г. наук I. А. Сіроченко), фізіології фотосинтезу (канд. хім. наук Х. М. Починок), біохімії рослин (д-р біол. наук А. С. Оканенко), стійкості рослин (д-р біол. наук Д. П. Проценко), росту і розвитку рослин (д-р біол. наук Ф. Л. Калінін).

У 1958 р. було створено відділ застосування полімерів у сільському господарстві (завідувач - канд. хім. наук М. М. Савицька), який у 1964 p. було передано Інституту органічної хімії. У 1959 р. на базі лабораторії фізіології фотосинтезу був створений відділ фізіології та екології фотосинтезу (д-р біол. наук А. С. Оканенко).

У травні 1962 р. Інститут повернули в систему Академії наук УРСР, при цьому він був перейменований на Інститут фізіології рослин. 3 метою розширення фундаментальних теоретичних досліджень було створено нові відділи: у 1962 р. - біофізики і радіобіології (на базі лабораторії застосування радіоактивних ізотопів, завідувач - д-р біол. наук Д. М. Гродзинський), фізіології взаємовідносин рослин і нижчих організмів (канд. біол. наук А. В. Манорик), у 1964 р. - біохімії фотосинтезу (д-р біол. наук Л. К. Островська), у 1966 р. - фізіології дії гербіцидів (канд. біол. наук Ю. Г. Мережинський), у 1968 р. - водного режиму рослин (д-р біол. наук С. І. Слухай). У 1980 р. створено лабораторію фізіологічних основ селекційного процесу (канд. біол. наук Г. С. Пономарьов), у 1984 р. відділ взаємовідносин рослин і нижчих організмів перейменовано на відділ симбіотичної азотфіксації (д-р біол. наук Ю. П. Старченков). 
У 1973-1974 рр. Інститут очолював відомий фізіолог рослин чл.-кор. АН УРСР А. В. Манорик, у 1974-1985 pp. - видатний фізіолог рослин і радіобіолог, д-р біол. наук, академік НАН України Д. М. Гродзинський.

У 1986 р. Інститут фізіології рослин АН УРСР після приєднання генетичних відділів Інституту молекулярної біології і генетики АН УРСР генетик і селекціонер, Герой України, академік НАН України В. В. Моргун реорганізував в Інститут фізіології рослин і генетики НАН України.

Інститут входить до складу Відділення загальної біології НАН України. Нині в його структурі налічують шість наукових відділів: генетичного поліпшення рослин, генетичної інженерії, фізіології та екології фотосинтезу, фізіології живлення рослин, симбіотичної азотфіксації, фізіології дії гербіцидів та лабораторії: біохімії фотосинтезу, захисту рослин, оригінального насінництва, якості зерна; відділ науково-технічної інформації та маркетингу, що включає також наукову бібліотеку.

В Інституті створено унікальну колекцію цінних зразків озимої пшениці й кукурудзи - сорти, популяції, унікальні мутантні й рекомбінантні лінії, інбредні лінії ІФРГ НАН України, яку включено до Державного реєстру наукових об'єктів, що становлять національне надбання.

Об'єктом зі статусом національного надбання є також одна з найбільших в Україні Колекція штамів симбіотичних та асоціативних азотфіксуючих мікроорганізмів, яку створили й підтримують у життєдіяльному стані співробітники Інституту.

Наукові здобутки вчених Інституту відзначено Ленінською премією, трьома Державними преміями СРСР, десятьма Державними преміями України, дев'ятнадцятьма преміями НАН України імені видатних учених, премією президентів академій наук України, Білорусі, Молдови, премією НААН України «За видатні досягнення в аграрній науці».

У спеціалізованій вченій раді науковці захищають докторські та кандидатські дисертації з двох спеціальностей - фізіології рослин і генетики.

Здобувачами вчених ступенів докторів i кандидатів наук були співробітники Інституту, науковці з інших установ Національної академії наук України, Національної академії аграрних наук України, вищих навчальних закладів України, а також громадяни Росії, Білорусі, Грузії, Азербайджану, Казахстану, Латвії, Молдови, Польщі, Індії, В’єтнаму, Сенегалу.
В Інституті фізіології рослин і генетики НАН України були започатковані й успішно функціонують відомі наукові школи з експериментального мутагенезу та теоретичних основ селекції рослин (засновник і керівних - академік НАН України В. В. Моргун), фізіології живлення рослин (засновник - академік АН УРСР і ВАСГНІЛ П. А. Власюк), фізіології та екології фотосинтезу (засновник - чл.-кор. АН УРСР А. С. Оканенко), фізіології симбіотичної азотфіксації (засновник чл.-кор. АН УРСР А. В. Манорик).

Протягом усіх років своєї діяльності Інститут підтримуе й розвиває традиції наукових шкіл, зберігає наступність поколінь, творчу атмосферу, що дає змогу не тільки успішно виконувати найскладніші завдання, а й постійно залучати до наукових досліджень талановиту молодь.

Починаючи з 1969 р. Інститут видає науково-теоретичний журнал «Физиология и биохимия культурных растений», який з липня 2013 р. перейменовано на «Физиология растений и генетика». ЗЖурнал публікує результати оригінальних досліджень, огляди, короткі повідомлення, методичні статті, що стосуються основних аспектів фізіології, біохімії, генетики й селекції рослин, клітинної й молекулярної біології, біотехнології та екології, а також рецензії на нові книги, інформацію про наукові з'їзди, координаційні наради, реферати депонованих статей. ЖЖрнал має добрі традиції, заслужив повагу серед наукової спільноти й посідає чільне місце серед провідних наукових періодичних видань України. Він представлений в Українському реферативному журналі «Джерело», ДАК (біологічні науки). Визнанням його на міжнародній арені є представлення у реферативних і наукометричних базах, зокрема BIHITI, Thomson Reuters (Biological Abstracts, BIOSIS Previews).

В Інституті працює Рада товариства молодих учених, діяльність якої сприяє залученню талановитої молоді Інституту до наукової та науково-організаційної роботи. Рада один раз на два роки організовує конференції молодих учених з проблем фізіології, генетики, біотехнології рослин і мікроорганізмів.

Інститут координує роботу Українського товариства фізіологів рослин, а також є співорганізатором проведення його з'їздів.

Ефективною формою ознайомлення з науковими розробками Інституту та організації впровадження їх у виробництво є проведення щорічних міжнародних науково-практичних конференцій «День поля» за участю керівників і фахівців сільськогосподарських 
товариств і підприємств з усіх областей України, насіннєвих базових господарств Інституту, відповідальних керівників Міністерства аграрної політики та продовольства України, керівників обласних і районних управлінь сільського господарства зон Степу, Лісостепу й Полісся, народних депутатів України, науковців, закордонних гостей.

Наукові підрозділи Інституту виконують дослідження за такими основними напрямами:

- з'ясування фізіолого-біохімічних і молекулярно-генетичних закономірностей стійкості та адаптації рослинних систем;

- дослідження фотосинтезу, мінерального живлення рослин, біологічної азотфіксації та можливостей використання біологічно активних речовин і сполук із гербіцидною активністю;

- вивчення механізмів генетичних процесів з метою розроблення наукових основ селекції рослин;

- збереження й раціональне використання рослинних генофондів, створення нових біота нанотехнологій, отримання й вивчення генетично модифікованих організмів.

Дослідження виконують понад 100 науковців, у тому числі один академік НАН України, один академік НААН України, два чл.-кор. НАН України, 14 докторів і понад 56 кандидатів наук. діли.

Стисло охарактеризуємо структурні підроз-

Відділ фізіології живлення рослин входить до складу Інституту від часу його заснування після переведення з Інституту ботаніки АН УРСР, де його організував у 1939 p. академік АН УРСР і ВАСГНІЛ П. А. Власюк, який керував відділом до 1955 р. У подальші роки відділ очолювали: д-р с.-г. наук I. А. Сіроченко (1955-1958), канд. біол. наук П. П. Мельничук (1958-1966), д-р с.-г. наук О. Д. Хоменко (1966-1980), д-р біол. наук, лауреат премії імені М. Г. Холодного НАН України (нині академік НААН України) I. М. Гудков (1981-1987), д-р біол. наук, лауреат премії імені М. Г. Холодного НАН України К. С. Ткачук (1987-2000), канд. біол. наук Ж 3. Гуральчук (2001-2003), канд. біол. наук М. Ф. Михальський (2003-2005). 32005 р. відділом керує д-р біол. наук, професор, чл.-кор. НАН України В. В. Швартау.

Результати досліджень співробітників відділу відзначені Державною премією України в галузі науки і техніки та тричі - премією імені М. Г. Холодного НАН України, опубліковані в 27 монографіях, захищені 53 авторськими свідоцтвами й патентами. У відділі підготовлено 40 кандидатів і 5 докторів наук.
Роботи відділу проводять за активної співпраці з колегами з країн ЄС, Білорусі, Мексики, Австралії, Швейцарії та інших країн.

\section{Основні наукові напрями:}

- з'ясування механізмів метаболізму іонів для підвищення продуктивності та збереження родючості грунтів, створення високоефективних добрив і систем захисту, біофортифікації;

- розроблення сучасних аналітичних методів на основі іонної хроматографії та емісійної спектроскопії, математичного аналізу для дослідження компонентів агрофітоценозів;

- визначення молекулярних механізмів регуляції іонного гомеостазу культурних рослин.

Світовий пріоритет мають дослідження академіка П. А. Власюка щодо фізіологічної ролі марганцю в живленні рослин, встановлення біологічної ролі молібдену, бору, цинку, кобальту й літію. Розроблено органо-мінеральну систему живлення рослин у сівозмінах $\mathrm{i}$ вдосконалено технології рослинництва країни шляхом масштабного впровадження мінеральних добрив з мікроелементами.

Пріоритетними у відділі є дослідження основ продукційного процесу. Розроблено фізіологічні основи живлення високопродуктивних сортів озимої пшениці та концепцію регуляції іонного гомеостазу, що є науковим фундаментом створення високоефективних технологій живлення.

Науковці відділу фізіологічно обгрунтували застосування рідких амонійних добрив на посівах зернових культур.

Розроблено високоефективні інтегровані системи живлення та захисту культурних рослин, що широко впроваджуються багатьма провідними сільськогосподарськими підприємствами України і забезпечують вагоме зростання додаткового фінансування Інституту.

Відділ симбіотичної азотфіксації (до 1984 p. - відділ взаємовідносин рослин і нижчих організмів) створено в 1962 р. на базі лабораторії фізіології дії ізотопів. У різні роки відділ очолювали чл.-кор. АН УРСР, д-р біол. наук, професор А. В. Манорик, д-р біол. наук, професор, лауреат премії імені М. Г. Холодного НАН України Ю. П. Старченков. 31998 р. відділом керує чл.-кор. НАН України, д-р біол. наук, професор С. Я. Коць. Співробітники відділу є авторами 14 монографій, 32 патентів і авторських свідоцтв, а також понад 800 статей у провідних фахових наукових виданнях.

Наукові праці співробітників відділу отримали широке визнання. Вони удостоєні двох Державних премій України в галузі науки і техніки, премії імені М. Г. Холодного та премії імені Д. К. Заболотного НАН України, 
медалі та п'ятьох премій НАН України для молодих вчених, премії Кабінету Міністрів України та премії Верховної Ради України для молодих вчених.

Відділ підтримує тісні наукові зв'язки 3 Університетом Західної Угорщини, Інститутом фізіології рослин ім. академіка М. Попова Болгарської АН, Інститутом кормових культур Болгарської АН, Інститутом генетики і цитології НАН Білорусі та науковими установами інших країн.

3 часу створення у відділі підготовлено 6 докторів і 29 кандидатів наук. Нині у відділі працює 17 наукових співробітників, серед яких 2 доктори, 11 кандидатів біологічних i 1 кандидат хімічних наук.

\section{Основні наукові напряли:}

- вивчення механізмів процесу біологічної азотріксації для істотного підвищення рівня біологічного перетворення атмосферного азоту мікроорганізмами-азотфіксаторами;

- генетичне конструювання і селекція нових штамів азотфіксувальних бактерій з поліпшеними симбіотичними характеристиками;

- інтенсифікація процесу зв'язування молекулярного азоту та розроблення заходів щодо оптимізації умов для максимальної реалізації генетично закладеного азотфіксувального потенціалу макро- та мікросимбіонтів.

Співробітники відділу симбіотичної азотфіксації встановили, що відповідальний за фіксацію молекулярного азоту фермент нітрогеназа складається 3 двох металовмісних білкових компонентів - залізо- і молібдензалізовмісних. Доведено, що нітрогеназа бактероїдів люпину за багатьма фізико-хімічними параметрами є подібною до нітрогенази, виділеної з інших мікроорганізмів-азотфіксаторів. 3'ясовано, що чисті культури бульбочкових бактерій здатні синтезувати нітрогеназу й фіксувати молекулярний азот.

Зроблено вагомий внесок у вивчення взаємозв'язків азотфіксації, фотосинтезу й дихання, впливу мінерального азотного живлення та регуляторів росту рослин на інтенсивність цих процесів у бобових культур. Науково обгрунтовано роль симбіотичної азотфіксації в підвищенні продуктивності зернобобових культур i багаторічних бобових трав за рахунок біологічного азоту.

Науковці відділу за більше ніж 35 років створили й підтримують у життєдіяльному стані одну з найбільших в Україні колекцій мікроорганізмів-азотфіксаторів. Колекцію включено до Державного реєстру наукових об’єктів, що становлять національне надбання.

Відділ фізіології та екології фотосинтезу створено в 1959 р. Першим його завідувачем був чл.-кор. АН УРСР, д-р біол. наук А. С. Оканенко. 31979 р. відділ очолював д-р біол. наук, професор Б. І. Гуляєв, з 2000 по 2008 рр. - д-р біол. наук Т. М. Шадчина, з 2009 р. відділом керує д-р біол. наук О. О. Стасик. Результати досліджень співробітників відділу відзначено Державною премією СРСР, Державною премією УРСР у галузі науки і техніки, двічі - премією імені М. Г. Холодного НАН України, опубліковано в 13 монографіях, захищено 30 авторськими свідоцтвами й патентами. У відділі підготовлено 41 кандидата i 10 докторів наук. Роботи відділу проводять в активній співпраці із закордонними дослідницькими лабораторіями: Колчестерського університету, Університету Данді, Шотландського інституту рослинництва, Ротамстедської дослідної станції (Велика Британія), Університету Балеарських островів (Іспанія).

\section{Основні наукові напряли:}

- регуляція фротосинтезу в донорно-акцепторній системі рослин;

- регуляція фотосинтезу за змінних умов довкілля у зв'язку з генетичним потенціалом стійкості рослин до абіотичних стресів;

- роль фотодихання в регуляції фотосинтезу та продукційного процесу рослин;

- взаємозв'язок фотосинтезу й продукційного процесу рослин на рівнях структурної організації хлоропласт-листок-рослина-посів.

Науковці відділу з'ясували механізми регуляції квантової ефективності фотосинтезу рослин за різних умов вирощування, дії стресових чинників і взаєморегуляції фотосинтезу та росту в донорно-акцепторній системі рослин. 3 використанням нових сучасних методів комплексно охарактеризовано структурно-функціональні особливості фротосинтетичного апарату на рівнях організації від субклітинного до ценотичного та механізми регуляції його активності в сучасних високоінтенсивних сортів озимої пшениці, що зумовлюють їхню перевагу за зерновою врожайністю. Розкрито фізіологічну роль фотодихання в регуляції фотосинтезу i реалізації генетичного потенціалу продуктивності та стійкості рослин. Виявлено показники фотосинтетичного апарату, що можуть бути використані для прогнозування врожайності та як фізіологічні маркери високої продуктивності в селекції озимої пшениці. Розроблено систему вуглекислотного підживлення тепличних рослин закритого грунту відхідними газами котелень, а також способи підвищення врожаю і його якості у рослин озимої та ярої пшениці, винограду, цукрового буряку, соняшнику й ріпаку. 
Лабораторія біохімії фотосинтезу (до 2016 р. - відділ біохімії фотосинтезу). Завідувач лабораторії - д-р біол. наук В. В. Шевченко.

Відділ засновано в 1964 р. згідно з Постановою Президії АН УРСР для вивчення світлової фази фотосинтезу. 31964 по 1984 pp. відділ очолювала заслужений діяч науки i техніки України, лауреат Державної премії СРСР, д-р біол. наук, професор Л. К. Островська, з 1984 по 2001 рр. - заслужений діяч науки і техніки України, лауреат Державної премії України, лауреат премії ім. М. Г. Холодного, д-р біол. наук, професор С. М. Кочубей. 32003 р. відділом керує д-р біол. наук В. В. Шевченко. 32016 р. відділ переведено у статус лабораторії.

У відділі підготовлено 16 кандидатів та 4 доктори наук. Розробки відділу опубліковано у 11 монографіях та 480 статтях у вітчизняних та закордонних виданнях, захищено 5 авторськими свідоцтвами й патентами, підтримано 10 міжнародними та 11 вітчизняними грантами. Розробки молодих вчених підтримано стипендіями фонду Дж. Сороса, Президії НАН України, Президента України, спеціальним грантом НАН України для молодих учених, відзначено премією Президента України.

\section{Основні наукові напрями:}

- вивчення організації та функціонування світлової фази фотосинтезу;

- дослідження процесів адаптації фотосинтетичного апарату до умов довкілля;

- розроблення методів дистаційного моніторингу стану сільськогосподарських посівів.

Співробітники розробили оригінальну динамічну модель організації гран хлоропластів на основі вивчення просторової гетерогенності фотосинтетичного апарату та швидких перебудов ультраструктури хлоропластів під дією короткочасних стресів.

Під час дослідження механізмів функціонування світлової фази фотосинтезу виявлено роль фосфопротеїнів у регуляції фотосинтетичного апарату, розроблено квантово-механічну модель обміну енергією збудження у пігментних комплексах фотосистеми I та виявлено особливості формування фотосинтетичного апарату за умов неповної сумісності ядерного та хлоропластного геномів, а також у разі вирощуванні рослин в умовах мікрогравітації.

Створено польовий спектрофотометр, в якому реалізовано оригінальний метод дистанційного визначення вмісту хлорофілу.

Відділ фізіології дії гербіцидів засновано у 966 р. 3 того часу і до 2000 р. його очолював канд. біол. наук Ю. Г. Мережинський.
32000 р. відділом керує д-р біол. наук Є. Ю. Мордерер. Співробітники відділу є авторами 7 монографій, 26 патентів і авторських свідоцтв. Значна частина досліджень здійснюється у співпраці з провідними світовими компаніями, виробниками засобів захисту рослин: «Байєр», «БАСФ» (Німеччина), «Дюпон», «Доу Агросаєнсис» (США), «Адама» (Ізраїль). Наукові досягнення відділу одержали високу оцінку. За цикл робіт «Фізіологічні основи регуляції вибірної фітотоксичності гербіцидів» канд. біол. наук Ю. Г. Мережинський, д-р біол. наук Є. Ю. Мордерер, д-р біол. наук В. В. Швартау у 2005 р. були нагороджені премією імені М. Г. Холодного НАН України. Ці вчені у складі авторського колективу за виконання роботи «Розробка та впровадження екологічно безпечних технологій боротьби з бур'янами» у 2010 р. були удостоєні Державної премії України в галузі науки і техніки.

\section{Основні наукові напрями:}

- механізми взаємодії гербіцидів у комплексах;

- механізми індукованого гербіцидами патогенезу;

- розроблення технологій захисту посівів сільськогосподарських культур від бур'янів.

Співробітники відділу довели участь процесу програмованої загибелі клітин у патогенезі, індукованому гербіцидами. Розкрито роль стану антиоксидантно-прооксидантної рівноваги рослин у детермінуванні їхньої чутливості до гербіцидів. Визначено основні закономірності ефектів взаємодії під час комплексування гербіцидів з різними механізмами фітотоксичності. На базі отриманих фундаментальних результатів розроблено та впроваджено екологічно безпечні технології контролювання бур'янів у посівах зернових колосових, кукурудзи, сої, ріпаку та овочевих культур.

Відділ генетичної інженерії був заснований у 1995 р. під керівництвом д-ра біол. наук Б. О. Левенка. 32001 р. відділом керує д-р біол. наук О. М. Тищенко. Співробітники відділу є авторами 11 монографій, понад 202 статей, виданих в Україні й за кордоном, 14 патентів та 6 авторських свідоцтв. У відділі підготовлено 2 доктори та 7 кандидатів наук. Співробітники відділу підтримують міжнародні зв'язки: з Віденським університетом (Laboratory of Plant Biotechnology, Max F. Perutz Laboratories, University of Vienna), IHститутом експериментальної ботаніки, Чеxiя (Institute of Experimental Botany, Academy of Sciences of the Czech Republic), з Інститутом цитології і генетики Сибірського відділення РАН, з Інститутом генетики і різіоло- 
гії рослин АН Молдови, з Центральним ботанічним садом НАН Білорусі.

Наукові досягнення співробітників відділу здобули широке визнання. За цикл робіт 3 біотехнології рослин у 2000 р. д-ру біол. наук Б. О. Левенку та канд. біол. наук М. О. Рубцовій присуджено премію ім. В. Я. Юр'єва. У 2010 р. за цикл робіт «Створення нових форм буряків генетичними та біотехнологічними методами» д-ру біол. наук О. В. Дубровній присуджено премію НАН України ім. В. Я. Юр’єва. За цикл робіт «Реалізація продуктивного потенціалу культурних рослин за дії стресових факторів» А. В. Бавола у 2010 р. нагороджено премією Президента України для молодих учених. У 2006-2010 pp. співробітники отримали 3 гранти та стипендії Президента України для молодих учених.

Основні наукові напряли:

- генетична інженерія культурних рослин;

- клітинна селекція на комплексну стійкість до абіотичних стресорів;

- фізіолого-метаболічні зміни в процесі трансгенезу культурних рослин;

- генетична та епігенетична мінливість геному в процесі морфогенезу in vitro;

- регуляція метаболізму вуглеводів.

Науково-дослідна робота відділу пов'язана з пріоритетним напрямом сучасної біології розробленням фундаментальних і прикладних питань генетичної інженерії та клітинної селекції для підвищення комплексної стійкості до несприятливих чинників довкілля важливих в Україні сільськогосподарських культур - пшениці, кукурудзи й соняшнику. Співробітники відділу запропонували оригінальні системи Agrobacterium-опосередкованої трансфромації рослин in vitro та in planta, пріоритетність яких підтверджена патентами України. Вперше експериментально обгрунтовано, що осмотолерантність трансгенних рослин кукурудзи й соняшнику з дволанцюговим РНК-супресором гена проліндегідрогенази є результатом змін в експресії гена, що проявляється на рівні активності ферменту та підвищенні рівня вільного проліну. Це свідчить на користь ефективності використання технології коротких інтерферуючих РНК для генетичного поліпшення рослин. Вперше встановлено зміни ферментно-вуглеводного комплексу в процесі трансгенезу in vitro та in planta, тоді як змін, пов'язаних з експресією генів запасних білків, не відбувається. Рекомендовано використовувати аналіз ферментів метаболізму сахарози у селекційно-генетичних програмах як маркерів добору трансгенних варіантів з поліпшеними фізіолого-генетичними показниками. Теоре- тично запропоновано та експериментально доведено ефективність використання летальних доз іонів важких металів для отримання стрес-стійких форм рослин до водного дефіциту й засолення.

Відділ генетичного поліпшення рослин створив академік НАН України В. В. Моргун у 2011 р. на базі відділу експериментального мутагенезу, який започаткував у 1966 р. лауреат Ленінської премії чл.-кор. АН УРСР, д-р біол. наук, професор В. П. Зосимович. У 1967-1973 рр. відділом експериментального мутагенезу керував д-р біол. наук, професор П. К. Шкварніков. 31974 р. й до цього часу його очолює академік НАН України, д-р біол. наук, професор В. В. Моргун.

У структурі відділу працюють три лабораторії: оригінального насінництва, якості зерна та захисту рослин.

Наукові досягнення відділу та створені сорти й гібриди рослин здобули високу оцінку та широке визнання далеко за межами України. Дослідження вчених відділу з проблем гетерозису, генетичних основ мутаційної селекції, створення ранньостиглих гібридів кукурудзи та принципово нового типу напівкарликових пшениць відзначено Державною премією СРСР у галузі науки і техніки, трьома Державними преміями України в галузі науки і техніки, премією президентів академії наук України, Білорусі й Молдови, преміями ім. В. Я. Юр'єва та ім. Л. П. Симиренка НАН України, премією НААН України «За видатні досягнення в аграрній науці».

За визначні особисті заслуги перед Українською державою у створенні й широкому впровадженні високопродуктивних сортів зернових культур, багаторічну плідну наукову та громадську діяльність В. В. Моргуну присвоєно звання Героя України з врученням ордена Держави.

Основні наукові напрями:

- дослідження генетичних механізмів формування корисних ознак рослин і теоретичних основ селекції;

- розроблення ефективних методів селекції, створення та впровадження у виробництво нових конкурентоспроможних сортів;

- створення й дослідження генетично модифікованих організмів для селекції високопродуктивних і стійких до несприятливих умов генотипів основних сільськогосподарських культур.

Широко відомі праці науковців відділу генетичного поліпшення рослин з питань теоpiї і методів гетерозисної селекції кукурудзи. Створені вченими ранньостиглі гібриди кукурудзи дали змогу значно розширити ареал 
посівів кукурудзи і вперше забезпечили отримання зерна там, де раніше ця культура не дозрівала, що сприяло значному підвищенню валових зборів зерна в Україні й країнах СНД. На сьогоднішній день науковці створили вже п'яте покоління гібридів кукурудзи, які придатні також для використання як сировина для біопалива. Генетичний потенціал нових гібридів досягає 14-16 т/га зерна і понад 100 т/га листостеблової маси.

Обгрунтовано генетичні основи та методи селекції принципово нового типу напівкарликових пшениць, створення і впровадження яких забезпечило зростання генетичного потенціалу цієї культури на 25-30\% і визначило базові основи «зеленої революції» в Україні. Із застосуванням принципів хромосомної інженерії були перенесені транслокації хромосом жита у геном пшениці. Саме завдяки цьому створено принципово нове покоління сортів озимої пшениці, які забезпечили отримання рекордних урожаїв 12,40-13,18 т/га зерна пшениці за всю багатовікову історію України. Серед них - 'Смуглянка', 'Колумбія', ‘Золотоколоса', ‘Фаворитка' та ін. Широко визнано, що сорти озимої пшениці селекції ІФРГ НАН України найбільш вдало поєднують високу продуктивність з високою стійкістю до посухи та морозів. Науковці розробили методичні основи фізіологічної генетики, використання молекулярних маркерів у селекції пшениці на високу якість зерна, продуктивність та грунтово-кліматичну адаптивність. Ці дослідження започатковують в Україні новий напрям генетичного поліпшення рослин - молекулярну селекцію.

Науковці відділу виконали унікальні дослідження, пов'язані з генетичною загрозою, що виникла внаслідок аварії на Чорнобильській AEC. Отримано дані, які підтверджують, що Чорнобильська зона навіть через 30 років після аварії залишається генетично небезпечною.

Відділ розвиває новий напрям наукових досліджень - отримання в Україні врожаїв зернових понад 10 т/га. Це нова для України філософія хліба, що дасть змогу вивести нашу державу на рівень передових країн Свропи.

Унікальну колекцію цінних зразків озимої пшениці та кукурудзи включено до Державного реєстру наукових об'єктів, що становлять національне надбання.

В. В. Моргун є засновником широковідомої наукової школи 3 експериментального мутагенезу та теоретичних основ селекції рослин. Наукові праці співробітників відділу органічно поєднують фундаментальні дослідження з розв'язанням актуальних прик- ладних проблем державного значення. В. В. Моргун і співавтори створили 145 сортів i гібридів різних культур (пшениця, кукурудза та ін.), занесених до Державного реєстру сортів рослин, придатних для поширення в Україні. Наукова новизна закріплена 235 авторськими свідоцтвами й патентами. Укладено та забезпечується дія і науковий супровід 3044 ліцензійних договорів на використання сортів селекції відділу у виробництві. Районовані сорти й гібриди експонувались на численних виставках і були відзначені медалями, почесними дипломами й грамотами. Створені співробітниками відділу сорти злакових культур протягом 38 років висівали на полях України та країн СНД. Площа посівів цих сортів у різні роки становила від 1 до 5,5 млн га, що є вагомим внеском у розв'язання проблеми продовольчої безпеки.

Лабораторія якості зерна (керівник - канд. біол. наук В. М. Починок) проводить дослідження молекулярно-генетичних основ якості зерна пшениці, поліморфізму геному рослин, удосконалення селекційного процесу на основі використання ДНК-маркерів. Науковці лабораторії визначають генетичну чистоту ліній i сортів рослин, розробляють експрес-методи для оцінювання селекційного матеріалу.

Основним завданням лабораторії оригінального насінництва (керівник - канд. біол. наук В. П. Оксьом) є розроблення наукових основ виробництва оригінального насіння для підвищення рівня впровадження наукових досягнень Інституту.

Лабораторія захисту рослин (керівник канд. с.-г. наук Т. В. Топчій) досліджує поширення хвороб і шкідників рослин у селекційних посівах, розробляє технології їхнього захисту.

Дослідне сільськогосподарське виробництво Інституту (директор - канд. біол. наук В. П. Оксьом, смт Глеваха, Васильківський p-н, Київська обл.) є центром впровадження у виробництво нових сучасних сортів і передових наукових технологій не лише в Київській області, а й в усій Україні. В господарстві щорічно вирощують насіння високих репродукцій принципово нових сортів озимої пшениці селекції Інституту, розмножують насіння кращих сортів ярих культур. Наукове керівництво господарством з боку Інституту дає можливість проводити дослідження 3 поліпшення технологій вирощування, збільшувати віддачу кожного гектара землі за дотримання заходів екологічної безпеки.

Відділ науково-технічної інформації та маркетингу (керівник - В. В. Вакуленко) створено в 2004 р. на базі реорганізованого 
відділу науково-технічної інформації для підвищення ефективності маркетингових досліджень, впровадження наукових розробок Інституту, патентно-дослідницької діяльності, надання інформації, реалізації продукції Інституту та його Дослідного сільськогосподарського виробництва. Співробітники відділу надають консультації щодо оформлення заявок на винаходи та подання їх до Інституту інтелектуальної власності, а також допомогу в отриманні патентів. Проводять постійну роботу з презентації та рекламування науково-технічної продукції Інституту. Особливу увагу приділяють впровадженню у виробництво нових перспективних високоврожайних сортів озимої пшениці, гібридів кукурудзи, оформляють виробникам насіння ліцензії на право вирощування й реалізації насіннєвого матеріалу зернових культур селекції Інституту.

Відділ регулярно організовує участь підрозділів Інституту в спеціалізованих сільськогосподарських виставках, бере активну участь у підготовці та проведенні щорічної науково-практичної конференції «День поля» на дослідних полях Інституту.

При Інституті фізіології рослин і генетики НАН України створено мережу базових господарств у різних агрокліматичних зонах України, яка щорічно розширюється. Діяльність цієї мережі має важливе значення, ос- кільки її основною метою є вирощування високоякісного насіння і впровадження у сільськогосподарське виробництво країни нових високопродуктивних сортів озимої пшениці та гібридів кукурудзи, якими славиться Інститут, нових комплексних мінеральних добрив, бактеріальних добрив, бакових сумішей гербіцидів.

Вчені Інституту приділяють належну увагу розвитку молекулярно-генетичних досліджень, поглибленню досліджень у галузі генетичного поліпшення рослин, фізіології мікро- та макроелементів, симбіотичної азотфіксації, фотосинтезу, вивченню ролі сигнальних, епігенетичних i фізіолого-біохімічних процесів у формуванні продуктивності й стійкості рослин, нанотехнологій, отриманню й вивченню генетично модифікованих організмів. Пріоритетним напрямом діяльності Інституту є широкомасштабне впровадження наукових розробок у сільськогосподарське виробництво та примноження хлібного достатку нашої держави.

Славну дату 70-річчя Інституту співробітники зустрічають сповненими сил та енергії для досягнення нових успіхів у науковій та практичній діяльності. Колектив Інституту й надалі плідно працюватиме на благо України, відстоюватиме їі інтереси та сприятиме вирішенню питань продовольчої безпеки нашої Батьківщини. 